a) Archiwum i Biblioteka Kapituły Metropolitalnej, Kraków . 2509 str.

b) Biblioteka OO. Franciszkanów, Kraków . . . . . . $120 \mathrm{str}$.

c) Biblioteka OO. Dominikanów, Kraków . . . . . . 1576 str.

d) Biblioteka OO. Bernardynów, Kraków . . . . . . 1210 str.

Razem zmikrofilmowano: 5415 str.

2) Mikrofilmowanie zbiorów archiwalnych: ${ }^{\circ}$

a) Archiwum Kurii Metropolitalnej w Krakowie, Wizytacje kościołów t. 1, 2, 3, 4, 5, 6, 7, 8, 9, 10, 12 i 15 . . . . 3686 str.

3) Mikrofilmy zakupione przez Ośrodek ABMK:

a) „Ecclesiastica" zakupione w Bibliotece Narodowej w Warszawie 128 pozycji, ok. $3160 \mathrm{mb}^{?}$

b) Procesy informacyjne biskupów polskich od końca XVI wieku do r. 1870 - Archiwum Konsystorskie i Archiwum Datarii Apostolskiej, Watykan, 9492 str. $^{8}$

5. Prace na kowo-usługowe

a) Rozesłano kwestionariusz do bibliotek kościelnych w Polsce, celem sporządzenia centralnej ewidencji kościelnych zbiorów bibliotecznych.

b) Opracowano polską bibliografię archiwów, bibliotek i muzeów kościelnych. Kontynuowano prace nad zagraniczną bibliografią kościelnych zbiorów archiwalnych (w wyborze) ${ }^{9}$.

c) $\mathrm{Na}$ podstawie literatury drukowanej opracowano obecny stan kościelnych zbiorów archiwalnych.

d) Sporządzono mapę hierarchii Kościoła rzymsko-katolickiego w Polsce $(1: 500000)$ z oznaczeniem kościelnej sieci zbiorów archiwalnych, bibliotecznych i muzealnych.

e) Pośredniczono w zakupie druków bibliotecznych i bibliograficznych oraz odpowiedziano na liczne zapytania naukowe $i$ fachowe (m. in. z Francji, Niemiec i Zw. Radzieckiego) z dziedziny archiwistyki, bibliotekarstwa i muzealnictwa (m. in. udzielono kilkudniowej porady fachowej na miejscu przy urządzaniu Biblioteki Archidiecezjalnego Seminarium Duchownego we Wrocławiu).

O. AMBROŻY JASTRZEBSKI OFM Cap.

\title{
PIERWSZY KURS BIBLIOTEKARSKI OO. KAPUCYNÓW PROWINCJI WARSZAWSKIEJ
}

Koleje losu, jakie zakon Kapucynów w Polsce przechodził w czasach porozbiorowych, sprawiły, że w Nowym Mieście n. Pilica powstał znaczny księgozbiór klasztorny. Oto bowiem z ówczesnej prowincji polskiej pozo.

- Inwentarz zmikrofilmowanych pozycji ukaże się w niniejszym czasopiśmie.

7-8 Inwentarz nabytych pozycji mikrofilmów ukaże się w niniejszym organie.

"Obie bibliografie ukażą się $w$ następnych tomach tego czasopisma.

Archiwa, Bibliotekì i Muzea Kościelne -. T. 4 
stającej pod zaborem rosyjskim, która po uzyskaniu niepodległości przemianowana została na prowincje warszawską, nie uległy kasacie tylko dwa klasztory: lomżyński i nowomiejski. Książki więc z pokasowanych klaszto. rów przewożono do obu tych klasztorów, które ocalały a zwłaszcza do Nowego Miasta, gdzie tą drogą powstała duża biblioteka. Tu też mieściło się archiwum prowincji.

Obie wojny światowe wyrządziły wiele szkody tym zbiorom archiwalnym i bibliotecznym.

Uporządkowaniem ich po ostatniej wojnie zajął się O. Ambroży z Wołkowska (Jastrzębski), mianowany w czerweu 1959 r. archiwistą i bibliotekarzem prowincjonalnym. Prace swą rozpoczął on od archiwum a następnie przystąpił do reorganizacji księgozbioru. Najpierw trzeba bylo przygotować lokal, wymagający gruntownego rimontu. Zmieniono więc sufit, założono centralne ogrzewanie i instalację elektryczna, uzupełniono, przerubiono i pomalowano drewniane regały pod ścianami. $\mathrm{Na}$ środku ustawiono regaly metalowe o wysokości $4 \mathrm{~m}$. Zastosowano tak znaczne wymiary regałów, aby wykorzystać jak najbardziej przestrzeń, i dostosować je do istniejących regałów drewnianych. Sporządzono szafkę katalogową z 96 szufladkami. Następnie skomasowano w Nowym Mieście starodruki z Warszawy i Łomży. Po przeprowadzeniu dezinsekcji i dezynfekcji książek zagrożonych i od kurzeniu calości zbiorów, ustawiono je na regałach, dzieląc starodruki według wieków i formatów, oraz wydzielając jako osobną grupę polonica. Dopiero po dokonaniu tych wstępnych czynności, można było przystąpić do skatalo-. gowania księgozbioru.

Aby wykonać tego rodzaju prace zgodnie ze współczesnymi wymaganiami, zwrócił się O. Ambroży - na życzenie najprzew. Ojca prowincjała Benignusa Sosnowskiego, który nie szczędzi potrzebnego nakładu na archiwum i biblioteke prowincji - do Osrodka Archiwum Bibliotek i Muzeów Kościelnych $z$ prośbą o pomoc $w$ zorganizowaniu kursu bibliotekarskiego. $\mathrm{Z}$ ramienia Ośrodka wyjechali do Nowego Miasta jako wykładowcy kursu dyrektor Biblioteki Uniwersyteckiej KUL o. dr Romuald Gustaw OFM i wicedyrektor tejże Biblioteki mgr Jan Wiśliński. Kurs trwał od 5 do 10 czerwca $1961 \mathrm{r}$.

O. dyrektor Gustaw w 15 godzinach wykładów objął calość problematyki odnoszącej się do organizacji biblioteki kościelnej lącznie z wiadomościami teoretycznymi z zakresu nauki o książce i techniki pracy umysłowej. Mgr Jan Wiśliński zajął się problematyką katalogu alfabetycznego. W ciągu następnych czterech dni trwania kursu zapoznał uczestników z zasadami katalogowania druków zwartych nowych, wydawnictw ciągłych i starych druków. Pod jego kierunkiem odbywało się katalogowanie tego rodzaju materiałów bibliotecznych.

Uczestników kursu było 13. Reprezentowane były wszystkie klasztory prowincji: Lubartów, Lublin, Łomża, Nowe Miasto, Orchówek, Rywałd, Serpelice, Warszawa i Zakroczym, razem 9.

ALFABETYCZNY WYKAZ UCZESTNIKOW KURSU

1. O. Gabriel ${ }^{1}$ Bartoszewski $z$ klasztoru w Zakroczymiu,

2. O. Wincenty Czajkowski $\mathrm{z}$ klasztoru $\mathrm{w}$ Warszawie,

1 Imiona sa zakonne. 
3. O. Urban Drożdż z klasztoru w Rywałdzie,

4. O. Zdzisław Gardocki z klasztoru w Lubartowie,

5. O. Ambroży Jastrzębski z klasztoru w Nowym Mieście,

6. O. Daniel Kordela $\mathrm{z}$ klasztoru w Rywałdzie,

7. O. Atanazy Niziolek z klasztoru $w$ Warszawie,

8. O. Anicet Pieńkowski $\mathrm{z}$ hospicjum ${ }^{2}$ w Serpelicach $\mathrm{n}$. Bugiem,

9. O. Edmund Różycki z hospicjum w Krynicy Morskiej,

10. O. Michał Skorupiński $\mathrm{z}$ klasztoru $\mathrm{w}$ Lublinie,

11. O. Albin Szymański z hospicjum w Orchówku n. Bugiem,

12. O. Eugeniusz Wenta $z$ klasztoru $w$ Eomży,

13. O. Agrypin Zajkowski z klasztoru w Nowym Mieście.

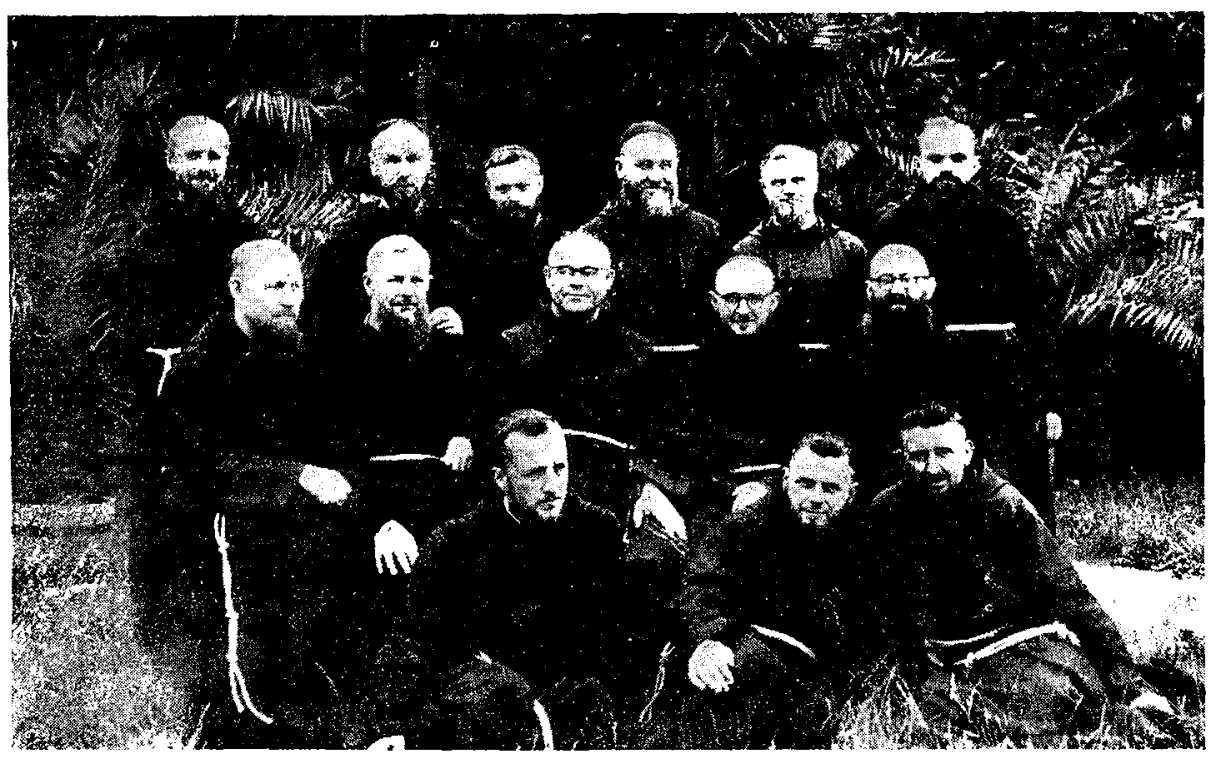

O. dyr. R. Gustaw $w$ otoczeniu uczesiników kursu

Po skończonym kursie część uczestników pozostała jeszcze czas pewien w Nowym Mieście, aby pomóc O. Ambrożemu w opracowaniu zbiorów. Skatalogowano księgozbiór podręczny. Wszyscy uczestnicy kursu wynieśli z wykładów i ćwiczeń wiele korzyści i wyrażają swoją wdzięczność za zorganizowanie tego pierwszego w dziejach prowincji warszawskiej kursu bibliotekarskiego.

2 Hospicjum - klasztor niepelny, nie mający 6 zakonników. 